\title{
Effect of Instructional Model and Learning Materials Towards Competency in Using and Regulating of Electrical Motor
}

\author{
Baharuddin \\ Electrical Engineering Education Department, Faculty of Engineering, State University of Medan, North Sumatra, Indonesia
}

Email address:

Baharunimed@gmail.com

To cite this article:

Baharuddin. Effect of Instructional Model and Learning Materials Towards Competency in Using and Regulating of Electrical Motor. Education Journal. Vol. 4, No. 4, 2015, pp. 166-169. doi: 10.11648/j.edu.20150404.14

\begin{abstract}
The interest of this research is learner's competency in using and regulating of electrical motor based on teaching models and instructional materials used. Data are obtained through quasi-experimental study with a number of 60 learners as a sample, which it was taken randomly. A sheet test and an observation sheet are used as the research instrument, which was developed and tested in advance. Data are analyzed by ANOVA, and concluded that there is a difference of the effect of learning models and forms of teaching materials used towards the learners' competency in using and regulating of an electric motor.
\end{abstract}

Keywords: Instructional Models, Learning Materials, Competency

\section{Introduction}

A person in charge of a work must be competent in that field in order to guarantee the quality of his work. Competencies represent an approach that is popular in practice $[1,2]$. The competence of someone is the ability to channel and apply knowledge and skills to face the new situation. This is a picture of a qualitative nature of the person's behavior when doing the job [3].

Competence looks of skill, power, authority, and the finesse of someone on rational action based on the expected conditions (Makmun \& Abin Syamsuddin, 1996). Someone is important to have the competence to be able to contribute to something of high value at the level of individual and social life, and that makes competence as an instrument to deal with the demands and challenges of a complex [4].

A competency can be awakened through a variety of learning activities with opportunities for learners to conduct investigations and experiments [5]. A considerations used in assessing learning outcomes is the success of the students to realize a theory, and analogies and represents the variables contained in the theory [6,7]. In accredit work-based learning student in connection with the development of competencies is conducted through a learning model in the form of practicum, ie meaningful as objects or concepts used in presenting something [8].

A model of learning is becoming a learning process that is intended to allow the learners to understand the material, namely through a systematic procedure of organizational learning experience. And this is a conceptual framework for achieving learning objectives, and serves as a guideline for the designers of learning and teachers in planning learning activities $[9,10,11]$. Selection of the learning model is determined by several factors, including the circumstances of a learner and the learning environment. The decision can be taken by considering a model that will be selected [12].

Dick and Carey model is selected in this study because of its development stages suitable as a basis to draft consisting of 10 steps with a clear relationship, uninterrupted relationship between the stage of each other. Based on the form of the strategy has been envisaged to be played when the learning process. Learning strategy here is a fusion of a sequence of events, ways of organizing the subject matter and students, equipment and materials, as well as the time spent in the learning process [13]. Besides teacher qualifications and school facilities, another important determinant of quality of education is the teaching and learning materials. It is essential for quality materials to be made available to the teachers and students in adequate quantities to support the teaching and learning processes. Different people learn in different ways is a fact of the classroom and something that teachers often try to overcome (Online).

In practice, the learning materials are often used in the module form, but it seems not to provide maximum results. 
Learning materials need to be developed with opportunities for learners to build it-self. Learners as knowledge constructors share some fundamental features from, whether working individually or in groups, on traditional screen-based structures or within more of webpage hypertext architecture. They develop diverse skills in data/ media selection, generation, organization, orchestration and re-structuring. The opportunity to share the results of construction labor with others permits these active learners to gain feedback as to whether their level of understanding is sufficient to facilitate meaningful communication of ideas to others [14].

The packaging of teaching materials can be in variety form, namely printed materials and ingredients are not printed. In this study, the printed instructional materials used is module, and unprinted teaching materials are packaged in compact disk. The using of learning materials packed in CD can increase student motivation and student learning outcomes. Learning materials can be packaged such that fun learners, and can relieve the boredom of students when learning $[15,16]$. It became the basis of this study that the teaching materials are built in the form of animation that is packaged in a Compact Disk (CD), namely the use and regulation of the electric motor in the form of animation. The teaching materials are included in the experiment of learning model i.e. Dick \& Carey model of learning and conventional learning models.

\section{Method}

A Quasi-experimental design was used with $2 \times 2$ factorial design. The effects of learning models and teaching materials were analyzed in teaching the learning materials in the CD animation form and modules. The learning models used in this study are Dick \& Carey model and conventional learning model. The influence of the learning model and instructional materials used were viewed in the competence of the learner in using and regulating the electric motor.

This study involved 60 students as a samples, which took randomly, and are grouped into two experimental groups. Each group consisted of 30 students. Data on students' competency in using and regulating electric motors, is obtained through a test sheet related to the students' knowledge and observation sheet used to see the attitude and skills of students. All the instruments used in this study was developed by the researchers and tested first to see the level of reliability and validity of the instrument. Students' competence is determined by the composition of the assessment of knowledge, attitudes and skills in using and regulating of electricmotors. Data was analyzed by two ways ANOVA. The advanced test was done to see the best group among of the existing groups.

\section{Results}

Data was analyzed to obtain the necessary information relating to the Mean value, Standard deviation. Summary of the results of calculations of data from each treatment group are presented in Table 1 .

Table 1. Description of the research data.

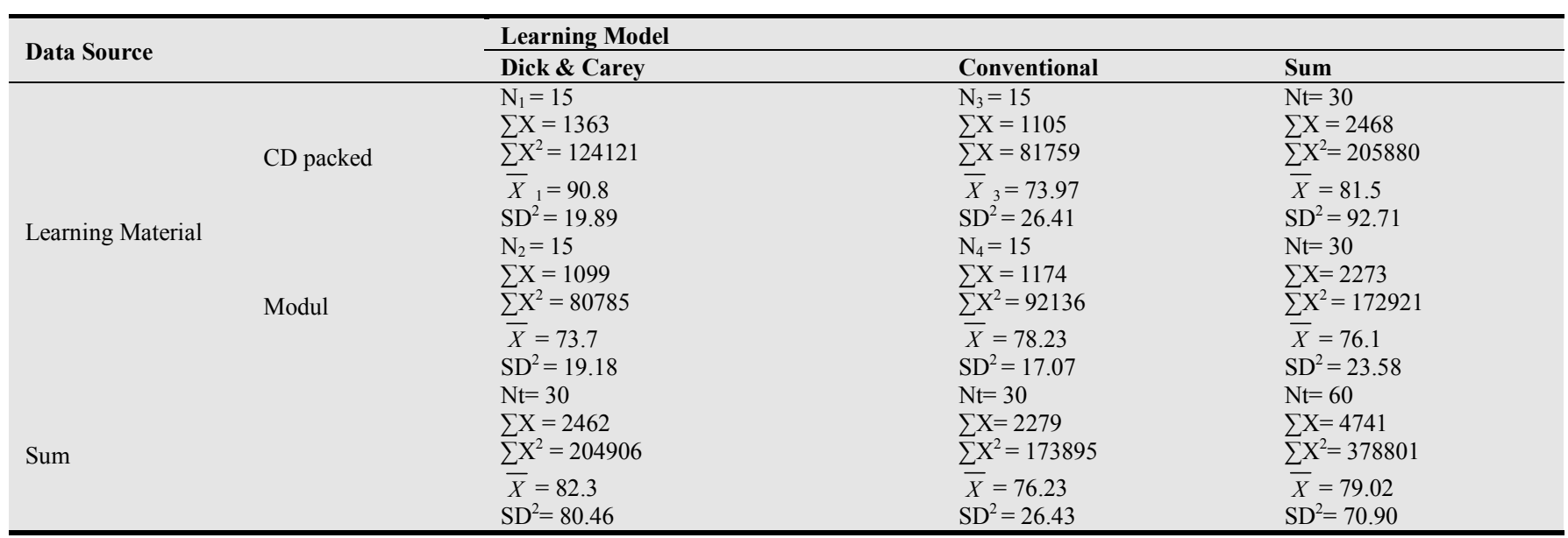

The results of calculations of data in Table 1, became the basis for the calculation of the assumptions test. The results obtained are the terms of normality and homogeneity requirements. The next test is the test of analysis of variance of the data, which are summarized in Table 2 below.

Table 2. Results of Analysis of Variance.

\begin{tabular}{|c|c|c|c|c|c|c|}
\hline Source of Variance & Sum of Square (SS) & DF & Mean Square & $\mathbf{F}$ & $\mathrm{P}(\alpha=.05)$ & Description \\
\hline Learning Model (A) & 558.1499 & 1 & 558.1499 & 27.3476 & 2.772 & Significant \\
\hline Learning Material (B) & 633.7499 & 1 & 633.7499 & 31.0517 & 2.772 & Significant \\
\hline Interaction of $\mathrm{A}$ and $\mathrm{B}$ & 1848.1503 & 1 & 1848.1503 & 90.5534 & 2.772 & Significant \\
\hline Betwee Groups & 3040.0501 & & & & & \\
\hline Within Groups & 1142.9332 & 56 & 20.4095 & & & \\
\hline Total & 4182.9833 & 59 & & & & \\
\hline
\end{tabular}


In the Table 2 appears the calculation analysis of variance between columns (learning model), obtained $F=27.3476$ and $\mathrm{pF}_{\text {table }}=2,772$ for the significance level $\alpha=0: 05$ with degrees of freedom df (1: 56). It shows the average results of the use and regulation of competence electric motor that students learned with Dick \& Carey learning model $(=82.30)$ is higher than the average competence of the use and regulation of electric motors students who learned with conventional learning model $(=76.23)$.

Likewise, the results of the analysis of variance of the effect of teaching materials, obtained $\mathrm{Fh}$ of 31.0517 and price $\mathrm{F}_{\text {table }}=2,772$ for the significance level $\alpha=0.05$ with degrees of freedom df (1: 56). It shows the average results of the use and regulation of competence electric motors students with learning materials animation higher $\mathrm{CD}(=81.50)$ than the average competence of the use and regulation of electric motors students with learning materials module $(=76.10)$.

The results of testing the interaction between learning model with the teaching materials used, $\mathrm{ieFh}=90.5534$ and $\mathrm{F}_{\text {table }}=2,772$ for the significance level $\alpha=0$ :05 with $\mathrm{dk}=$ (1:56). On this basis it appears that the competence of the use and regulation of electric motorsor the students with learning materials animation CD packed, which learned with Dick \& Carey model of learning, is higher $(=90.80)$ than the competence use and regulation of electric motors of students with module learning materials $(=73.70)$. And the competence in using and regulating of an electric motor of students with learning materials animation $\mathrm{CD}$, learned with conventional learning model is lower $(=73.97)$ than the competence in using and regulating of the electric motor of student which learn with module learning materials $(=78.23)$. It shows that there is an interaction between learning models and learning materials to affect the competency of using and regulating electric motor of students. Based on further testing is done to see which of the best combination of the combination of existing treatment.

Tuckey test conducted showed $\mathrm{Q}=12.5680$ higher than $\mathrm{Q}_{\text {table }}=3.03$ at significance level $\alpha=0.05$. It gives the sense that the competence of the use and regulation of electric motors students with learning materials animated CD packed of the lessons learned with Dick \& Carey model, is higher (= $90.80)$ than in the use of learning modules $(=73.70)$. Further calculations $\mathrm{Q}=3.1310$ smaller than $\mathrm{Q}_{\text {table }}=3.03$ at significance level $\alpha=0.05$ is meant that the average competence of the using and regulating of an electric motor of students with learning materials animation $\mathrm{CD}$, which learned with conventional learning models, lower $(=73.97)$ than the competence which learn with the module learning material $(=78.23)$. Likewise $\mathrm{Q}=12.3695$ is higher than $\mathrm{Q}_{\text {table }}$ $=3.03$ confidence level $\alpha=0.05$. It shows the average of the competence of the using and regulating electric motors of student, with learning materials animation CD packed, learned with Dick \& Carey model of learning is higher (= 90.80) than the competence of students with learning materials animation $\mathrm{CD}$ packed, which learned with conventional learning model $(=73.97)$. The next test results showed $\mathrm{Q}=3.3294$ is higher than $\mathrm{Q}_{\text {table }}=3.03$ at significance level $\alpha=0: 05$. It shows the average of the competence of the using and regulating of electric motor, which learned with learning model Dick \& Carey is lower $(=73.70)$ than the competence of students with learning materials module, which learned with conventional learning model $(=78.23)$. Summary of test results from the combination treatment group are presented in Table 3 below.

Table 3. Summary of Tukey test results.

\begin{tabular}{llll}
\hline \multirow{2}{*}{ No } & \multirow{2}{*}{ Groups } & Tukey Test & \\
\cline { 3 - 4 } & & $\mathbf{Q}$ & $\mathbf{Q}_{\text {table }}=\mathbf{0 . 0 5}$ \\
\hline 1 & A1 against A2 & $8.9225^{*}$ & 2.895 \\
2 & B1 against B2 & $7.9377^{*}$ & 2.895 \\
3 & A1B1 against A2B1 & $12.3695^{*}$ & 2.895 \\
4 & A1B1 against A1B2 & $12.5680^{*}$ & 3.03 \\
5 & A1B2 against A2B2 & $3.3294^{*}$ & 3.03 \\
6 & A2B1 against A2B2 & $3.1310^{*}$ & 3.03 \\
\hline
\end{tabular}

Description:

A1: Dick \& Carey Learning Strategy.

A2: Expocitory Learning Startegy.

B1: CD Packed

B2: Module.

A1B1: Competence practices and the use of electric motors settings student with accompanying materials

CD package that learned with Dick \& Carey learning strategy.

A1B2: Competence practice the use and regulation of electric motors students with materials accompanying modules learned with Dick \& Carey learning strategy.

A2B1: Competence practice the use and regulation of electric motors students with materials

Accompanying CD package that learned with expository learning strategy.

A2B2: Competence practice the use and regulation of electric motors students with materials accompanying modules learned with expository learning strategy.

\section{Discussion}

[17] look at the instructional design as a system and consider learning is a systematically process. This systematic way of working always refer to the general stages of learning development system (Instructional Systems Development/ISD), namely stages of analysis, design, development, implementation, and evaluation. All components interact in the learning process to achieve its intended purpose. This is the determinant in this study that the competence of the students in the use and regulation of the electric motor, which is taught using learning model Dick \& Carey, better than the competence of students who are taught by conventional models. All elements of the learning model role for the implementation of learning in order to obtain better results than the conventional learning model. This is in line with the statement of [18] that the use of Dick \& Carey model of learning in the learning provides the better outcome 
due to the sequential stages of proper instructional designing and presentation-provided in the Dick and Carey offered models have a better understanding of the difficult, concepts by the learners.

Likewise, teaching materials are included in the study, it turns teaching materials are packaged in the form of a compact disk (in the form of animation), learning outcomes (competencies) are better, compared with the use of teaching materials in the form of modules. This is in line with the statement of the experts that, to create meaningful learning experience allowing applicable moments of student learning, instructional Several strategies are suggested: matching instructional level to students' competency levels, use of identical elements between learning and application settings [19], and variation in the modality of instructional delivery to promote near and far transfer of learning [20]

Based on the findings of this study that Dick \& Carey learning model that includes instructional materials are packaged in the form of animation is much more successful than the other combinations. This implies that to get maximum learning outcomes when applying Dick \& Carey model, which included teaching materials need to be made in bentu animation. The advantage of using teaching materials are packaged in the form of animation, make the learners can directly replicate all the steps shown in the animation [21].

\section{Acknowledgement}

The author thanks to Mr. Hamonangan Tambunan, Lecturer of Electrical Engineering Educational Department, Faculty of Tecnical State Unviversity of Medan for his help.

\section{References}

[1] Boyatzis, R. E. (2008). Competencies in the 21st Century. Journal of Management Development, 27(1), 5-12.http://dx.doi.org/10.1108/02621710810840730.

[2] Schippmann, J. S., Ash, R. A., Battista, M., Carey, L., \& Eyde, L. D., Hesketh, B., et al. (2000). The Practice Of Competency Modeling. Personnel Psychology, 53, 703-740. http://dx.doi.org/10.1111/j.1744-6570.2000.tb00220.x.

[3] Masnur Muslich (2009). KTSP Pembelajaran Berbasis Kompotensi dan Kontekstual. Jakarta, Bumi Aksara.

[4] Makmun, \& Abin Syamsuddin (1996). Pengembangan Profesi dan Kinerja Tenaga Kependidikan. Pedoman dan Perkuliahan. Bandung, PPS. IKIP.

[5] Rychen, D. S. (2002) Key Competencies for the Knowledge Society.A Contribution from OECD ProjectDefinition and Selection of Competencies (DeSeCo). Education - Lifelong learning and the Knowledge Economy, Conference in Stuttgart, October 10-11.

[6] Nolker, Helmut, \& Schoenfeldt, E. (1983).
PendidikanKejuruan: Pembelajaran Kurikulum Dan Perencanaan. Jakarta. Online: http://www.ehow.com/list_6542858_types-learning-materials. html).

[7] Watkins, Ryan, Schlosser, \& Charles (2000). Capabilities Based Educational Equivalency Units: Beginning professional Dialogue. The American Journal of Distance Education, 4(3).

[8] Trianto (2010). Mendesain Model Pembelajaran Inovatif-Progresif. Jakarta, Kencana.

[9] Acher, MaríaArcà, \& NeusSanmartí (2007).Modeling as a Teaching Learning Process for Understanding Materials: A Case Study in Primary Education.Wiley Interscience, 91(3), 398-418. http://dx.doi.org/10.1002/sce.20196.

[10] Hamid, \& Abdul, K. (2009). Teori Belajar dan Pembelajaran. Medan, PPS Unimed.

[11] Ruhimat, \& Toto (2011). Kurikulum dan Pembelajaran.Jakarta: PT. Rajawali Pers.

[12] Chi, \& Robert, T. H. (1992). Using An Integrated Model Learning System To Construct The Model Base Of A Decision Support System. International Journal Of Intelligent Systems, 7(4), 373-389. http://dx.doi.org/10.1002/int.4550070406.

[13] Suparman, \& Atwi, M. (2004). DesainInstruksional. Jakarta, Universitas Terbuka.

[14] Harper, Barry, Hedberg, \& John (1997). Creating Motivating Interactive Learning Environments: a Constructivist View. Online: www. curtin.edu.au.

[15] Hung, et al. (2002). Taiwanese freshmens' listening strategies in watching an interactive CD-Room.Taiwan. National Huwei University of Science \& Technology.26, 65-74.

[16] Kristiyono, \& Agus. (2012). Perbedaan prestasi belajar matematika antara siswa yang diajar dengan modul dan CD interaktip pada materi fungsi di SMK PGRI 02. Salatiga.

[17] Dick, W., Carey, L. J. O., \& Carey (2005). The Systematic design of Instruction. Boston, New York, Walter Dick and Lou Carey.

[18] Bello, Hassan, \& Aliyu, U. O. (2012). Effect of 'Dick and Carey instructional model' on the performance of electrical/ electronics technology education students in some selected concepts in technical colleges of northern Nigeria. Educational Research, 3(3), 277-283.

[19] Baldwin, T. T., \& Ford, J. K. (1988). Transfer of training: A review and directions for future research. Personnel $\begin{array}{ll}\text { Psychology, } & 4(1),\end{array}$ http://dx.doi.org/10.1111/j.1744-6570.1988.tb00632.x.

[20] Clark, R., \& Taylor, D. (1992). Training problem solving skills using cognitive strategies: Novice versus expert problem solvers. Performance and Instruction, 31(3), 1-5. http://dx.doi.org/10.1002/pfi.4170310303.

[21] Lim, D. H., \& Morris, M. L. (2009). Learner and Instructional Factors Influencing Learning Outcomes within a Blended Learning Environment.Educational Technology \& Society, 12(4), 282-293. 